\title{
Psychological Aspects of the Role of Religion in Identity Construction
}

\author{
Pierre-Yves Brandt
}

Published online: 7 May 2013

(C) Springer Science+Business Media New York 2013

\begin{abstract}
Religious plurality can generate fears through identity destabilization. Religions offer ressources for coping with fears. On one side, production of stereotypes follows a defensive way. On the other side, claim to be universal help to cross boundaries and to cope with stigmatization, misrecognition and discrimination. Coping strategies combine at least five aspects: community, intimate relationship, rules, construction of identity, and worlview. This article shows how these aspects are intertwined.
\end{abstract}

Keywords Religion - Identity construction $\cdot$ Coping strategies $\cdot$ Religious attachment Conversion

Confrontation with cultural diversity is a consequence of migration. It offers chances for broadening ones worldview, for discovering new attitudes, ideas. The encounter with the other can also generate fears through identity destabilization, and enhance defense mechanisms.

The various contributions to this special issue show how such encounters produce boundary work and need of meaning. Both migrants and host populations are engaged in identity work: negotiation of identity is requested in the dialogue between self-identification and external categorization. The need to maintain a positive social identity and self esteem easily leads to psychological essentialism.

These various contributions also show how religion is involved in these processes. Religion can be instrumentalized in boundary work. Reference to religion can serve the reinforcement of ethnic differences. Moloney et al. (2013), for example, show how caricatures use stereotypes of Muslims for building hetero-referentiality. The same can be observed in Germany in the debate about integration of Muslims (Holtz et al. 2013). Participants of focus groups with German Muslims complain of collective discrimination: Islam is often associated with terrorism and fanaticism and essentialized. Psychological essentialism connected to religious identity leads to consider religion as unidimensional. If, for example, "Turkishness" is identified with 
Islam seen as leading to fanaticism, "Germaness" will be located on the opposite side of this dimension, on the tolerance side. With descriptions of this kind, it is easy to conclude that Turks have nothing in common with Germans.

Facing such discourses, Duemmler and Nagel (2013) show how important it is to be aware of the community aspect of religion which can hinder social integration. They also show how it is possible to work on diversity inclusion.

For their part, scholars in the study of religions have the responsibility to denounce an ideological manipulation of the concept of religion. Indeed, fair descriptions of religions conclude of their multidimensionality (Hill et al. 2000). For example, already more than 40 years ago, Stark and Glock (1968) describe religion as fivedimensional, including beliefs, knowledges, experiences, practices (subdivided into private and public), and consequences. That is why each individual has the possibility to organize his or her own religiosity, giving more importance to some aspects and less to others, as illustrated in the contribution of Baucal and Zittoun (2013). There are different ways to be Jewish, Muslim, Christian, etc.

Production of religious stereotypes is a manner to cope with religious plurality, but it is only a defensive way to build (individual or collective) identity. It is only one possible way among many others.

From the perspective of coping strategies, religion offers ressources on various levels. As suggested elsewhere, five aspects are intertwined in coping stategies (Brandt et al. 2012): community, intimate relationship, rules, construction of identity, and worlview. Collective activities and affiliation help to answer the need for social integration (community aspect). Relationship to an attachment figure helps to answer the need for security and protection (intimate relationship aspect). Prescriptions and prohibitions help to cope with the need for containing impulses, especially selfdestructive ones (rules aspect). Models and roles provided by religious traditions help to build the self and answer the need for identity and self-esteem (construction of identity aspect). The general framework for life supplied by a religious worldview answer the need for meaning-system (worlview aspect).

In this perspective of coping, the use of stereotypes and psychological essentialism are not only strategies for preserving identity and self-esteem; it combines the aspect of identity construction with the community aspect. It helps to feel socially integrated. Creation of boundaries is another way that combines these two aspects. It can result from the affirmation of a radical difference associated to religious affiliation. It is for instance the case of Mrs Ha in Hüwelmeier's report (2013). In this case, conversion expresses an exclusive understanding of religious membership. This solution was not only the personal choice of Mrs Ha, but also the result of environmental pressure. Changes in her ideas and behaviours could not be tolerated in the church she attended. Conversion is always the result of an identity negotiation on exclusivity (Brandt and Fournier 2009). In doing so, religion is used to cope with the fear of the other.

Nevertheless, religions offer also resources for crossing boundaries and coping with stigmatization, misrecognition and discrimination. Through their claim to be universal, religions contribute to modify meaning and values-systems (worldview aspect) and help to blur boundaries. Intra-group differentiation is another way to cope with boundaries. It combines the worldview aspect with the aspect of identity construction. This kind of coping process can be supported by a cognitive work on 
religious content. Baucal and Zittoun (2013) show how creativity can use religious resources in narratives for reorganizing self-identity and the person's relationships with the others. It is a manner to support self-esteem and the need for identity continuity and coherence.

The contribution of Baucal and Zittoun (2013) contains also illustrations of other aspects. The case of George Sand's dialogues with an imagined god is a good example of how religion can provide resources answering the need of attachment (intimate relationship aspect). Another example for the same aspect is the erection of an ancestor altar by Mrs Ha and its destruction when she converted from Buddhism to Pentecostal charismatic Christianity: the former relationship to the ancestors is replaced by the relationship to the Christian God. Sometimes, conversion is the only solution found by an individual for establishing a protective framework for a secure relationship to a spiritual figure.

Attachment theory has expanded through the work of John Bowlby (1991). According to him, attachment relationship refers to a close relationship that meets four criteria: proximity maintenance, safe haven, secure base, and separation distress (Hazan and Zeifman 1999). Following Bowlby, Mary Ainsworth (Ainsworth et al. 1978) has shown how the first attachment figures are replaced in adulthood by sexual partners, family members, or members of peer groups. It has been shown too, that spiritual figures (religious leaders, divines figures) can play the role of an attachment figure (Granqvist 2010). It is one of the main explanations of religious coping in patients suffering from schizophrenia (Rieben 2012). The relationship to a spiritual figure/object can help maintaining a sense of perceived security when in distress. Means for establishing a sense of proximity or closeness to a spiritual figure/object can be found in using symbols, engaging rituals, and prayer (Brandt et al. 2009).

In the case of Abraham, a young religious man (also in the contribution of Baucal and Zittoun. 2013), the work on preservation of identity is combined with a work on the obligations imposed by the Jewish law (rules aspect). The fact that religious people are less likely to use drugs or drink to much alcohol is well known (Koenig 1998). A recent survey in the general population of England compares people defining themselves as religious with people defining themselves as spiritual or neither religious nor spiritual. It shows that the persons defining themselves as religious are half as likely to use drugs or drink hazardously (King et al. 2013). Similarly, prevention of comorbidity (suicide attempts, drug or alcohol uses) is correlated with importance of religion in patients suffering from psychosis (Mohr et al. 2006; Huguelet et al. 2007).

This aspect of identity protection and preservation with the help of rules is also illustrated in the contribution of Endelstein and Ryan (2013) on clothing. Negotiation of identity is located at the interface between who I say I am (subjective identity) and who the others say I am (objective identity) (Brandt 1997). On the psychological level, negotiation of this kind requires the ability for using symbolic codes, here the dressing codes.

Religions are meaning-systems (Park 2005; Paloutzian 2005). For religious people, they influence all aspects of life and constitute central resources for the construction of identity, on the individual as well as on the collective 
level. Because of their global scope, they are especially helpful when people have to cope with distress, fears and identity destabilization. Nevertheless, they can also hinder openness to others in maintaining people in a worldview full of prejudices and stereotypes. Religion can help restore identity but it can also weaken it (Brandt et al. 2009) and provoke crises (Theissen 1999). The various contributions collected in this special issue document very well the multidimensionality of religions in their claim of making meaning.

\section{References}

Ainsworth, M. D. S., Blehar, M. C., Walters, E., \& Walls, S. (1978). Patterns of attachment: Psychological study of the strange situation. Hillsdale: Erlbaum.

Baucal, A., \& Zittoun, T. (2013). Religion as dialogical resource: a socio-cultural approach. Integrative Psychological and Behavioral Science. doi:10.1007/s12124-013-9229-z.

Bowlby, J. (1991). Attachment and loss (Vol. 3). Harmondsworth/Ringswood: Penguin Books.

Brandt, P.-Y. (1997). Identité subjective, identité objective: L'importance du nom. Archives de Psychologie, $65,187-209$.

Brandt, P.-Y., \& Fournier, C.-A. (2009). La conversion religieuse: Analyses psychologiques, anthropologiques et sociologiques. Genève: Labor et Fides.

Brandt, P.-Y., Fournier, C.-A., \& Mohr, S. (2009). Self-identity and religion/spirituality. In H. Koenig \& P. Huguelet (Eds.), Religion and spirituality in psychiatry (pp. 158-172). New York: Cambridge University Press.

Brandt, P.-Y., Mohr, S., Gillièron, C., Rieben, I., \& Huguelet, P. (2012). Religious coping in schizophrenia patients: spiritual support in medical care and pastoral counselling. The Toronto Journal of Theology, 28(2), 193-208. doi:10.3138/tjt.28.2.193.

Duemmler, K., \& Nagel, A.-N. (2013). Governing religious diversity: top-down and bottom-up initiatives in Germany and Switzerland. Integrative Psychological and Behavioral Science. doi:10.1007/s12124012-9226-7.

Endelstein, L., \& Ryan, L. (2013). Dressing religious bodies in public spaces: gender, clothing and negotiations of stigma among Jews in Paris and Muslims in London. Integrative Psychological and Behavioral Science. doi:10.1007/s12124-012-9228-5.

Granqvist, P. (2010). Religion attachment: the Godin award lecture. Archive for the Psychology of Religion, $32,5-24$.

Hazan, C., \& Zeifman, D. (1999). Pair bonds as attachments: evaluating evidence. In J. Cassidy \& P. R. Shaver (Eds.), Handbook of attachment: Theory, research, and clinical applications (pp. 336-355). New York: Guilford.

Hill, P. C., Pargament, K. I., Hood, R. W., Jr., McCullough, M. E., Swyers, J. P., Larson, D. B., et al. (2000). Conceptualizing religion and spirituality: points of commonality, points of departure. Journal for the Theory of Social Behaviour, 30, 51-77.

Holtz, P., Wagner, W., \& Dahinen, J. (2013). German Muslims and the 'Integration debate': negotiating identities in the face of discrimination. Integrative Psychological and Behavioral Science. doi:10.1007/ s12124-012-9227-6.

Huguelet, P., Mohr, S., Jung, V., Gillièron, C., Brandt, P.-Y., \& Borras, L. (2007). Effect of religion on suicide attempts in outpatients with schizophrenia or schizo-affective disorders compared with inpatients with non-psychotic disorders. European Psychiatry, 22, 188-194.

Hüwelmeier, G. (2013). Creating and refining boundaries - Church splitting among Pentecostal Vietnamese migrants in Berlin. Integrative Psychological and Behavioral Science. doi:10.1007/s12124-012-92258.

King, M., Marston, L., McManus, S., Brugha, T., Meltzer, H., \& Bebbington, P. (2013). Religion, spirituality and mental health: results from a national study of English households. The British Journal of Psychiatry, 202, 68-73.

Koenig, H. (Ed.). (1998). Handbook of religion and mental health. San Diego: Academic.

Mohr, S., Brandt, P.-Y., Borras, L., Gillièron, C., \& Huguelet, P. (2006). Toward an integration of spirituality and religiousness into the psychosocial dimension of schizophrenia. The American Journal of Psychiatry, 163(11), 1952-1959. 
Moloney, G., Wagner, P., \& Holtz, P. (2013). Editorial political cartoons in Australia: social representations $\&$ and the visual depiction of essentialism. Integrative Psychological and Behavioral Science. doi:10.1007/s12124-013-9236-0.

Paloutzian, R. F. (2005). Religious conversion and spiritual transformation: a meaning-system analysis. In R. F. Paloutzian \& C. Park (Eds.), Handbook of the psychology of religion and spirituality (pp. 331347). New York: Guilford.

Park, C. (2005). Religion and meaning. In R. F. Paloutzian \& C. Park (Eds.), Handbook of the psychology of religion and spirituality (pp. 295-314). New York: Guilford.

Rieben, I. (2012). Qualité de l'attachement dans la psychose et figures spirituelles, University of Lausanne, PhD Thesis, http://my.unil.ch/serval/document/BIB_4CB51B148384.pdf.

Stark, R., \& Glock, C. Y. (1968). American piety. Berkeley: University of California Press.

Theissen, G. (1999). A theory of primitive Christian religion. London: SCM.

Pierre-Yves Brandt is Professor of the Psychology of Religion at the University of Lausanne, Switzerland. His interests include children's representations of God, psychological construction of religious identity and religious coping among patients with schizophrenia. 